\title{
Advances in Omics for Enhancing Abiotic Stress Tolerance in Millets
}

CHARU LATA*

National Research Centre on Plant Biotechnology, Pusa Campus, New Delhi 110 012, India

CSIR-National Botanical Research Institute, Rana Pratap Marg, Lucknow 226 001, India

(Received on 18 October 2014; Revised on 31 December 2014; Accepted on 09 January 2015)

\begin{abstract}
Millets are small-seeded annual cereal crops which are mostly grown in marginal soils of arid and semi-arid regions, and consequently have to face several abiotic constraints that lead to reduction in the yield. Advanced biotechnological applications, particularly 'omics' approaches could serve as the most immediate and prospective strategies for improving abiotic stress tolerance in millet crops. Omics approaches lead to understand the mechanism of stress response and tolerance at molecular level through insights into gene, protein or metabolite profile and their phenotypic effects. Among millet crops, foxtail millet has been more intensively studied and characterized under abiotic stress conditions owing to its small genome size and diploidy. Genome-wide investigation and expression profiling studies have been extensively carried out in foxtail millet. However proteomic and metabolomic studies in response to abiotic stress in millets are still very limited. Some of the major quantitative trait loci (QTLs) controlling abiotic stress tolerance in millets have also been identified and mapped as for instance a major QTL for terminal drought tolerance in pearl millet and a major QTL for dehydration tolerance in foxtail millet. Gene manipulation for enhanced abiotic stress tolerance involving regulatory genes have proved to be more useful than using single or multiple stress responsive genes. Consequently, the recent advances in 'omics' technologies and accessibility to the genome sequences extend huge potential to enhance stress tolerance of millets. This review thus attempts to summarize various omics strategies and their applications in abiotic stress research in important millet crops namely foxtail millet, pearl millet and finger millet.
\end{abstract}

Key Words : Abiotic Stress; Genomics; Millets; Metabolomics; Omics; Phenomics; Proteomics; Transcriptomics

\section{Introduction}

Plants being sessile in nature are forced to thrive in stressful conditions originating either from physical environment (abiotic stress) or due to interactions with other living organisms (biotic stress). Abiotic stresses such as drought, salinity, water logging, extreme temperatures and heavy metals pose serious constraint to plant growth and development leading to yield reduction by more than $50 \%$ for major crop plants (Bray et al., 2000). Agricultural land that fall under non-stress category accounts for only $10 \%$ of the total arable land across the globe implying that crops raised on rest cultivable lands are subjected to one or more abiotic stresses (Dita et al., 2006). Moreover, crops which suffer abiotic stresses are usually more prone to weeds, insects, and pathogens adding up the losses considerably (Reddy et al., 2004). Response and adaptation in order to survive and reproduce under such stress conditions is a complex phenomenon and is by and large synchronized and adjusted by regulating crop's physiological, cellular and molecular activities (Chinnusamy et al., 2004; Ahuja et al., 2010). Hence understanding the mechanisms of plant stress tolerance and adaptation have long been the focal point of extensive and rigorous

*Author for Correspondence: E-mail: charulata14@ gmail.com 
studies by researchers. With the progression of omics technologies and functional characterization of individual genes, it has become evident that the environmental acclimatization which is crucial for plant survival is under strong regulation (Lopez et al., 2008; Muthamilarasan and Prasad, 2014; Kissoudis et al., 2014). It has been established that several components are involved in stress regulatory networks and may function synergistically or antagonistically to each other, thus promoting or compromising plant resistance to various abiotic stresses occurring separately or concurrently (Glazebrook, 2005; Kissoudis et al., 2014). Significant progress has been accomplished towards deciphering stress tolerance mechanisms not only in model crop like Arabidopsis but also in other crops like garden and woody species, cereals and millets (Bokhari et al., 2007; Alvarez et al., 2008; Caruso et al., 2009; Degenkolbe et al., 2009; Shulaev et al., 2008; Watkinson et al., 2008; Zellar et al., 2009; Ginzberg et al., 2009; Dwivedi et al., 2012).

'Millets' is a collective term used to refer a diverse group of small-seeded annual $\mathrm{C}_{4}$ Panicoid grasses such as foxtail millet (Setaria italica), pearl millet (Pennisetum glaucum), finger millet (Elusine coracana), proso millet (Panicum miliaceum) etc. that are cultivated as food and fodder crops, primarily grown on poor and marginal lands in dry areas of temperate, subtropical and tropical regions across the globe (Dwivedi et al., 2012; Lata et al., 2013). Millets characteristically adapt to unfavorable ecological conditions including abiotic and biotic stresses, demand least inputs and have remarkable nutritional properties. Nutritional quality of millet grains is usually equivalent or superior to other cereals with high amounts of carbohydrates, proteins, minerals, vitamins and essential amino acids (Dwivedi et al., 2012). Though millets rank sixth in world grain production after rice, wheat, maize, barley and sorghum, they are usually considered as a subsistence product and more often than not looked upon as a poor man's crop (Dwivedi et al., 2012; Lata et al., 2013). Noteworthy, India ranks first in global millet production with an annual production of $\sim 11$ million tonnes in 2013 (FAOSTAT, 2014; http://faostat.fao.org/site/567/Desktop Default.aspx?PageID=567\#ancor). Millets epitomize important genomic resources for agriculture as well as nutritional security of poor and marginal farmers that dwell in arid and semi-arid regions across the globe. Despite their significance, millets have largely been an under researched crop commodity as they are considered minor cereal crops of only regional importance, and hence little attention has been given for developing their genetic and genomic resources for use in crop improvement as compared to other staple cereals. Since millets are grown in low-input, rain-fed agriculture system, they tend to suffer from drought spells due to scarce, untimely and irregular rainfall that ultimately becomes major constraint for crop yield. Besides drought, soil salinity and high temperature are another major abiotic stress factors that severely affect crop growth and productivity. Therefore, it is important to improve abiotic stress tolerance in crop plants to ensure enhanced yield stability. Though conventional plant breeding along with good crop management practices have addressed several agronomic constraints that reduce crop yield or nutritional quality, there may be cases where the existing genetic resources do not possess the requisite traits. Yield losses due to abiotic constraints such as drought are highly variable in nature owing to stress timing, intensity and duration. Further breeding for drought tolerance through conventional approaches becomes even more difficult due to the occurrence of some location-specific stress factors such as high temperature or irradiance. Therefore advanced plant breeding practices supported effectively by cuttingedge genomics and genetic transformation technologies could lead to simpler and successful genebased approaches for enhancing abiotic stress tolerance of millet crops and thereby contributing to sustainable agriculture of dry regions. Among millets however, foxtail millet, pearl millet, and to lesser extent finger millet have lately started gaining some importance among the research community wherein 'omics' have played an important role apart from conventional plant breeding.

\section{The Concept of Omics and Abiotic Stress Tolerance in Millets}

Successful application of biotechnological approaches to overcome abiotic constraints entails a sound knowledge of both the target crop species and the 
underlying stress tolerance mechanisms that encompasses measurements from the whole plant to molecular level. Plant stress response is basically influenced by the type, duration, and severity of stress (Bray, 1997). Given that responses are governed by plant genome, recent efforts have been focused on decoding molecular response of the plants to abiotic stresses. Until recently, model plants such as Arabidopsis and rice were the focal point of research pertaining to studies on plant stress responses, while orphan crops like millets lagged far behind. Since large genome size and polyploidy hindered the basic goal to unravel the abiotic stress tolerance mechanisms in these naturally stress tolerant crops, recent progress in this area has been significantly enhanced by the development of foxtail millet as a model system to investigate evolution, physiology and the genetics of stress tolerance in millets. Foxtail millet has been the obvious choice for model millet crop owing to its small genome size, diploidy $(2 \mathrm{n}=2 \mathrm{x}=18)$, self pollination, short generation time and availability of efficient transformation platform (Lata et al., 2013). Powerful genetic and genomic tools such as isolation of expressed sequence tags (ESTs), genome sequencing, genetic and physical mapping, comparative mapping etc. have been thus established for the molecular genetic studies in millet crops (Dwivedi et al., 2012; Lata et al., 2013; Muthamilarasan and Prasad, 2014). The foxtail millet genome sequence and the high degree of synteny between foxtail millet and switch grass (Panicum virgatum), a bioenergy crop have a potential to facilitate genetic and genomic studies in related Panicoid crops (Lata et al., 2013; Lata and Prasad, 2013a).

Though sequence information is indispensable and essential starting point for molecular biology, it is alone not enough to resolve queries pertaining to stress responsive gene function, regulatory networks, and the biochemical pathways involved. Therefore, it becomes necessary to include more comprehensive approaches such as quantitative and qualitative analyses of gene expression products at the transcriptomic, proteomic, and metabolomic levels along with bioinformatics and systems biology approaches which will further allow a more specific use of marker assisted selection (MAS) and transgenic technologies (Dita et al., 2006). 'Omics' is generally used to refer all biotechnological applications that requires knowledge of stress response at molecular level including genomics, functional genomics, genetic engineering, gene expression, protein or metabolite profile(s) and their overall phenotypic effects in response to environmental perturbations which are generally accompanied by significant alterations in the plant transcriptome, proteome and metabolome (Ahuja et al., 2010; Fig. 1). Recently 'omic' approaches are being efficiently utilized to understand the molecular and genetic basis of abiotic stress perception, response and tolerance in millet crops. Transcriptome and expression profiling studies have been routinely carried out in various millet crops to identify candidate genes and regulatory networks involved in abiotic stress responses. Until now noteworthy progress has been achieved in abiotic stress research of major millets including foxtail millet, pearl millet, and finger millet as elaborated in the subsequent sections.

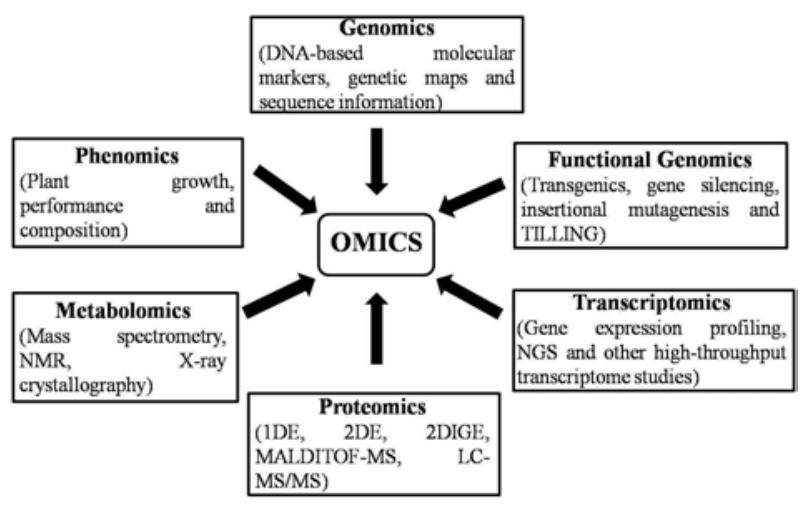

Fig. 1: A schematic representation of different Omics strategies

\section{Genomics}

Molecular markers, genetic maps and sequence information are some of the basic genomic resources required for genetic studies and molecular breeding approaches. Therefore genomics as a whole involves development of molecular markers and manipulation of quantitative trait loci (QTLs) through MAS for development of improved cultivars. These genomic resources facilitate breeding strategies for crop improvement programs by reducing the time- and labor-intensive direct screening of germplasm grown 
under field and green house conditions. Genetic maps and molecular markers also help in comparative mapping and synteny studies in crop plants, for example one of the recent studies have shown the synteny between pearl millet and foxtail millet chromosomes along with those of other grasses (Rajaram et al., 2013; Fig. 2). However discovery of DNA markers and construction of genetic linkage maps in millets have lagged behind other cereal crops such as rice, wheat and maize (Dwivedi et al., 2012). Among millets, mainly foxtail millet, pearl millet, finger millet, job's tear (Coix lacrymajobi) and tef (Eragrotis tef) have been investigated for development of genetic and genomic resources (Dwivedi et al., 2012).

\section{Foxtail Millet}

The availability of foxtail millet genome sequence together with genetic and physical maps provide valuable resources for powerful and efficient identification and characterization of genes and QTLs for various agronomic traits, thus facilitating marker- assisted breeding (MAB) and crop improvement. The first foxtail millet restriction fragment length polymorphism (RFLP)-based map consisting of 160 loci was constructed in an intervarietal cross (Wang et al., 1998) which was further proven to be useful in creating comparative genetic maps of foxtail millet and rice (Devos et al., 1998). Since then several groups reported on development of various genomic or EST based simple sequence repeat (SSR) markers to be used in diverse genotyping applications, phylogenetic and transferability studies in foxtail millet and other grass species (Jia et al., 2007; Jia et al., 2009; Heng et al., 2011; Gupta et al., 2012; Gupta et al., 2013). Considering the importance of intron length polymorphic (ILP) markers as genomic resources, Gupta et al. (2011) and Muthamilarasan et al. (2014a) developed 98 and 5123 ILP markers respectively in foxtail millet. The ILP markers from both studies showed to be useful in cross-species transferability, germplasm characterization, comparative mapping and genomic relationships studies between millets and non-millets.

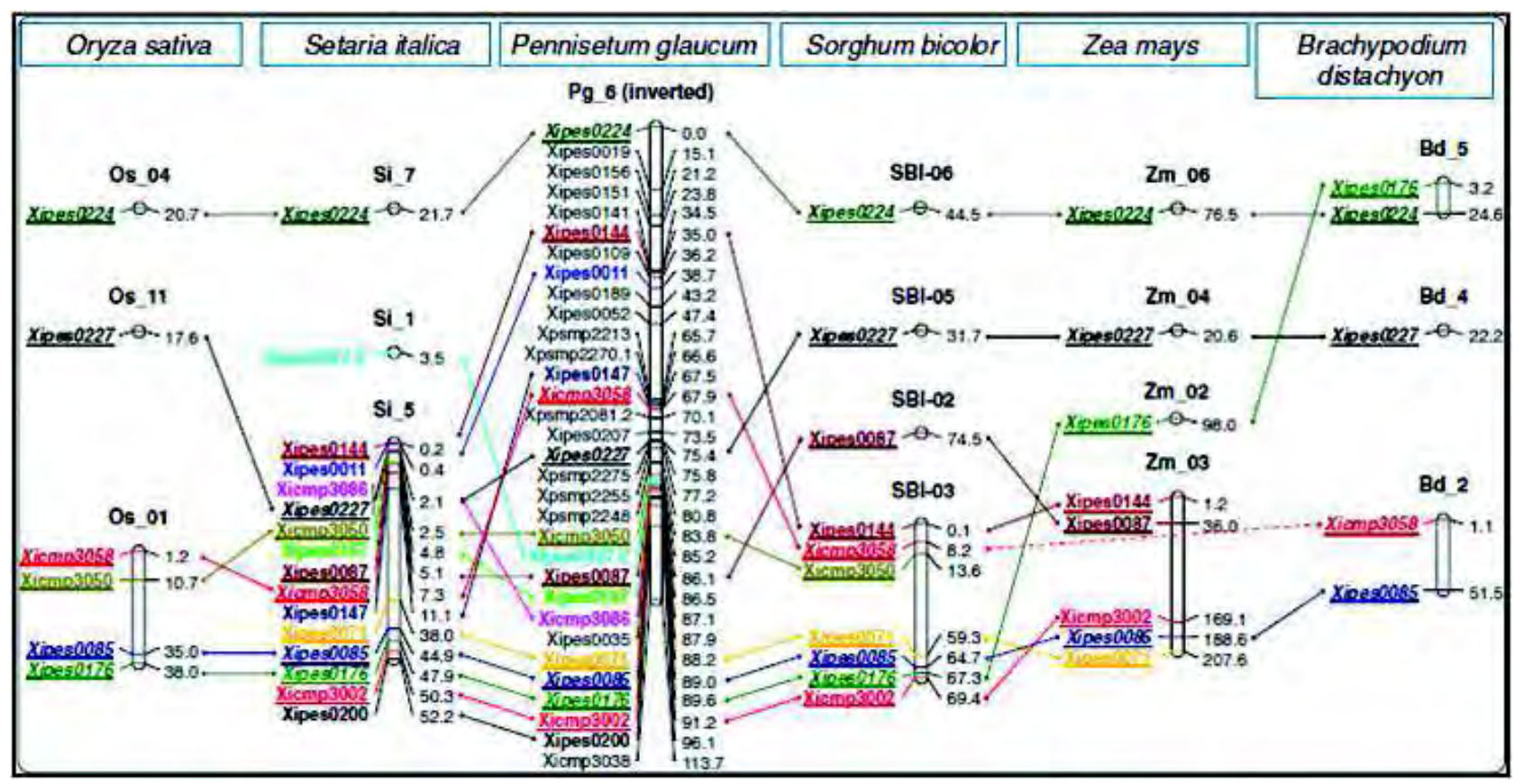

Fig. 2: A representation of synteny between pearl millet linkage group 6 (inverted) with five sequenced grass genomes including foxtail millet. Pearl millet has 7 (Pg_1 to Pg_7), foxtail millet has 9 (Si_1 to Si_9), rice has 12 (Os_1 to Os_12), sorghum has 10 (Sb_1 to Sb_10), maize has 10 ( $\mathrm{Zm} \_1$ to $\left.\mathrm{Zm} \_10\right)$ and Brachypodium has 5 (Bd_1 to Bd_5) linkage groups. EST-SSRs mapped on linkage group 6 of pearl millet. Linkage distances (in cM for pearl millet) or physical map positions (in Mb for other grasses) are given on the right side of each bar and the marker names are given on the left side of each bar. (Adapted from Rajaram et al., 2013) 
With the availability of Setaria genome sequence it has become possible for large-scale development of foxtail millet genomic resources (Bennetzen et al., 2012; Zhang et al., 2012). A foxtail millet landrace 'Shi-Li-Xiang' was resequenced to identify single nucleotide polymorphisms (SNPs), InDels, and structural variations (SVs) as compared to two foxtail millet reference genome sequences in order to expedite the identification of important candidate genes to be used for molecular breeding (Bai et al., 2013). Xu et al. (2013) developed a total of 9,576 and 7,056 SSR markers from 42,754 transcripts generated from referenced based assembly using foxtail millet genome and 60,751 transcripts from de novo assembly, respectively. Several other researchers also reported on identification of several microsatellite repeat motifs (Pandey et al., 2013; Zhang et al., 2014), eSSRs (Kumari et al., 2013), and transposable elements (TE)-based markers (Yadav et al., 2014a) using Setaria genome sequence data. In another interesting study, 176 microRNA (miRNA)-based molecular markers have been developed (Yadav et al., 2014b) from a set of 335 mature miRNAs (Khan et al., 2014). SNPs are single base substitution, insertion or deletion commonly found in a population and have recently been developed into powerful molecular markers. Lata et al. (2011a) identified a synonymous SNP associated with dehydration tolerance in a novel DREB2-like gene and developed an allele-specific marker (ASM) for the same. The ASM was validated in a core set of more than 100 foxtail millet accessions and the regression of lipid peroxidation (LP) and relative water content (RWC) on the ASM suggested that the SiDREB2-associated trait contributed to $\sim 27 \%$ and $\sim 20 \%$ of the total variation, respectively demonstrating the importance of this QTL for dehydration tolerance in foxtail millet (Lata and Prasad, 2012; Lata and Prasad, 2013b). Further, a total of 2,584,083 SNPs were identified from 916 diverse foxtail millet accessions, out of which 845,787 SNPs (minor allele frequency $>0.05$ ) were used to construct a foxtail millet haplotype map (Jia et al., 2013).

These marker resources are efficiently utilized time to time in genomics-assisted breeding. There have been several reports where molecular markers such as amplified fragment length polymorphism (AFLP), inter simple sequence repeat (ISSR) and SSRs have been used in assessing genetic relationships, studying domestication-related geographical structure and phylogenetic relationships between foxtail millet and wild relatives (Le Thierry d'Ennequin et al., 2000; Li et al., 2012; Wang et al., 2012), evaluating genetic diversity, population structure and linkage disequilibrium (LD) in various foxtail accessions $(\mathrm{Li}$ et al., 2012; Vetriventhan et al., 2014) as well as for examining important agronomic traits (Mauro-Herrera et al., 2013; Gupta et al., 2014) which once validated could be useful for identification of genes/QTLs linked with important traits and eventually in MAB of foxtail millet and related crops (Muthamilarasan and Prasad, 2014). To assist this, comprehensive online resources such as marker database (FmMDb; http:// www.nipgr.res.in/foxtail.html) (Suresh et al., 2013) and transcription factor database (FmTFDb; http:// 59.163.192.91/FmTFDb/) (Bonthala et al., 2014) have been constructed to provide the researchers and breeders unrestricted access to the developed genetic and genomic resources.

\section{Pearl Millet}

Pearl millet is one of the most hardy cereal crops grown for grain, forage and stover in the arid and semi arid tropical regions of Asia and Africa. It is an annual, small seeded, highly cross pollinated, $\mathrm{C}_{4}$ Panicoid cereal crop $(2 \mathrm{n}=2 \mathrm{x}=14)$ with a very large genome size $(\sim 2400 \mathrm{Mb})$ and short life cycle (Vadez et al., 2012). It has substantial stock of genetic and genomic resources with various DNA-based molecular markers including RFLP (Liu et al., 1994); sequence-tagged sites (STS; Devos et al., 1995); AFLP (Allouis et al., 2001); SSRs (Qi et al., 2004); diversity arrays technology (DArTs; Supriya et al., 2011); SNPs and conserved intron spanning primer (CISP) markers (Sehgal et al., 2012); mapping populations, and DNA-marker based linkage maps (Vadez et al., 2012; Sehgal et al., 2012). The genetic maps so developed have been demonstrated to be valuable not only for detection and breeding of promising QTLs for various traits (Jones et al., 1995; Morgan et al., 1998; Jones et al., 2002; Nepolean et al., 2006; Gulia et al., 2007; Bidinger et al., 2007) 
including terminal drought tolerance (Yadav et al., 2002; Yadav et al., 2004), components of drought adaptation (Kholová et al., 2012) and grain and stover yield (Yadav et al., 2003) but also for better understanding of complex relationships between pearl millet and other cereal crops (Devos et al., 2000).

A major QTL for terminal drought tolerance in pearl millet has been identified and mapped on linkage group 2 (LG 2) using segregating populations derived from two independent crosses between $\mathrm{H}$ 77/833-2 and PRLT 2/89-33, and ICMB 841 and 863B (Serraj et al., 2005; Bidinger et al., 2005; Bidinger et al., 2007). This QTL on LG 2 has been considered a major target for MAS for improving grain yield and grain stability across variable terminal stress conditions in pearl millet (Yadav et al., 2011). This DT-QTL has also been found to confer high leaf abscisic acid (ABA) and limiting transpiration rates at high vapor pressure deficits supporting the hypothesis of water saving mechanisms under well-watered conditions in drought tolerant pearl millet lines (Kholová et al., 2010). A major grain yield (GRYLD) QTL was also identified on LG 2 which also co-mapped with QTLs for harvest index (HI), grain number and grain mass under severe terminal stress (Bidinger, 2007). Other than these, several other QTLs associated with drought tolerance of grain yield in late stress environments were identified on various other linkage groups such as LG 3, 4, 5 and 6 (Yadav et al., 2004; Bidinger et al., 2007). Performance of LG 2 major QTL for terminal drought tolerance was also assessed under salt stress and interestingly it was found that this DT-QTL enhanced growth and productivity traits under saline and alkaline conditions by limiting $\mathrm{Na}^{+}$ accumulation in pearl millet leaves (Sharma et al., 2011). Another study established that the drought tolerant parent (PRLT 2/89-33) and two QTL-near isogenic lines (NILs) recorded higher yield under salinity stress at post-flowering growth stages as compared to drought sensitive parent (Sharma et al., 2014).

\section{Finger Millet}

Finger millet is another important climate resilient nutrimillet which has a rich resource of superior genes and alleles (Solanke and Mithra, 2013). It is an allotetraploid $(2 n=2 x=36)$ with genome designated as AABB. Breeding efforts in this crop have been limited owing to its highly self-pollinating nature and small flowers. Further, germplasm pool of this crop also remains largely uncharacterized with a very few reports in this regard to date based on morphological, nutritional and other quantitative traits (Prasada Rao and de Wet, 1997; Vadivoo et al., 1998; Upadhyaya et al., 2006). Dida et al. (2008) have reported wider level of genetic diversity among several domesticated finger millet cultivars through RAPD and microsatellite approach. Generation of a RFLP, AFLP and SSR marker-based genetic linkage map of its A and B genomes was the first major breakthrough in the area of finger millet genomics (Dida et al., 2007). A comparative analysis between finger millet and rice was carried out that revealed high level of conserved colinearity between gene orders. The study also led to deduce the supposed ancestral chromosome configurations in grass species. There have been quite a few reports on genomics studies for biotic stress resistance in finger millet (Panwar et al., 2010; Panwar et al., 2011; Babu et al., 2014), the same pertaining to abiotic stress research in finger millet is not available, and thus emphasizing the need of focused research in this regard.

Details of DNA-based molecular markers and genetic maps reported in foxtail millet, pearl millet and finger millet is given in Table 1.

\section{Functional Genomics}

In the post genomics era, comprehensive analysis using functional genomics technologies such as overexpression, gene silencing, insertional mutagenesis and targeted induced local lesion in genome (TILLING) have played an important role in improving our knowledge on complex regulatory networks associated with stress response, adaptation and tolerance in plants. Different omics technologies are also providing huge data sets which can be exploited to identify important candidate genes to be used in crop improvement programs through MAS or transgenic technology in millets. With the advancement of genome sequencing projects and proteomics, the 
Table 1. List of molecular markers and genetic linkage maps reported in foxtail millet, pearl millet and finger millet

\begin{tabular}{lll}
\hline DNA markers & Genetic maps & References \\
\hline Foxtail millet &
\end{tabular}

5123 Intron length polymorphic (ILP) markers

5020 highly repetitive microsatellites motifs

20,278 transposable element-based markers

176 miRNA-based markers

9,576 and 7,056 SSR markers

28, 342 microsatellites repeat motifs

534 eSSRs

64 genomic SSR markers

147 genomic microsatellite (SSRs) markers

98 ILP markers

One Allele-specific marker for SiDREB2 gene

$\sim 1000$ SNPs by sequencing pools of RILs

(S. italica acc. B100 x S. virdis acc. A10)

12 EST-derived SSRs

100 polymorphic SSRs from two

genomic DNA libraries

160 RFLP markers

Pearl millet

99 polymorphic EST-SSR markers

75 gene-based markers (SNP and CISP)

574 polymorphic DArT markers

58 EST- SSR primer pairs

19 EST-derived SSR primer pairs

16 EST-derived polymorphic SSRs

SSCP-SNP primer pairs

44 SSRs derived from genomic library

18 SSRs derived from genomic library

25 SSR markers from BAC library

Finger millet

36 EST-SSRs and 20 anchored-SSRs

3 EST-derived SSRs

31EST-derived SSRs

82 SSR markers
4049 ILP markers physically mapped on

9 foxtail millet chromosomes

A physical map of 733 highly polymorphic SSR markers developed

A high density physical map based on 28,342 microsatellites repeat motifs A physical map based on 327 eSSR markers

A genetic map with $~ 1000$ SNPs evenly mapped to all 9 chromosomes

A genetic map with 81 SSRs and 20 RFLP markers mapped onto 9 chromosomes covering $1654 \mathrm{cM}$ and marker density of $16.4 \mathrm{cM}$ 160 RFLP loci mapped onto 9 LGs spanning $964 \mathrm{cM}$

116 EST-SSRs, 53 genomic SSRs and 2 STS markers mapped on one or more of the four F7 RIPs

A genetic linkage map using 258 DArTs and 63 SSRs spanning $1148 \mathrm{cM}$

17 EST-SSR markers mapped to 5 of the 7 pearl millet LGs

A genetic map using 353 RFLP and 65 SSRs A genetic map with 61 RFLP and 30 SSR loci spanning $476 \mathrm{cM}$

A genetic map with 38 RFLP markers covering $280 \mathrm{cM}$

181 RFLP loci mapped to 7 LGs spanning 303 cM Liu et al., 1994

Nirgude et al., 2014

Nnaemeka, 2009

Arya et al., 2009

A genetic linkage map with 131 markers mapped to 16 LGs spanning $721 \mathrm{cM}$ on the A genome and 196 markers mapped to 9 LGs covering $787 \mathrm{cM}$ on the B Genome

332 loci from 266 primer pairs mapped to 26 LGs Srinivasachary et al., 2007 Highly conserved gene orders between rice and finger millet 
challenge remains to functionally validate hundreds and thousands of identified genes or proteins where reverse genetics strategies will be crucial. A powerful tool for determining function of a gene is to overexpress it in same or heterologous system under the control of a constitutive or stress-inducible promoter. While another important strategy to determine function of a gene is to suppress its expression or knock it out. Significant work regarding this has been initiated in millets.

\section{Transgenomics}

Transgenomics or transgenic technology is a targeted gene-based functional genomics tool which provides valuable information about regulatory mechanisms underlying stress tolerance in plants. Hence in recent years transgenic technology has widely been used for genetic improvement of many crop plants including major cereals. However, transgenomics in millets is still in nascent stage despite their economic and nutritional importance, though there are several reports where candidate genes from millets have been functionally validated in Arabidopsis or tobacco (Agarwal et al., 2007; Ramegowda et al., 2012; Yue, 2014). Most of the above candidate genes from millet crops are transcription factors (TFs) as they can regulate the expression of downstream stress responsive genes and thus play important role in imparting stress tolerance. Of note, several candidate TFs including AP2/ERFs, NAC, $\mathrm{C}_{2} \mathrm{H}_{2}$ zinc finger and MYB were analyzed in foxtail millet to identify suitable candidate genes which can be used for further characterization using transgene-based approaches towards engineering stress resistance (Lata et al., 2014; Puranik et al., 2013; Muthamilarasan et al., 2014b; Muthamilarasan et al., 2014c). In addition to TFs, several stress-responsive genes such as WD40, Dicer-like (DCL), Argonaute (AGO) and RNAdependent RNA polymerases (RDR) have been studied in foxtail millet to identify potential candidate genes for downstream characterization (Mishra et al., 2014; Yadav et al., 2014c). Despite these advances, development of protocols for generating transgenic lines in millets is still in its early stage. An efficient in vitro regeneration protocol particularly through somatic embryogenesis is crucial for establishment of successful transformation and recovery in any crop plant (Veluthambi et al., 2003). There have been quite a few reports on somatic embryogenesis and plant regeneration protocols in foxtail millet, pearl millet and finger millet (Kothari et al., 2005).

\section{Foxtail Millet}

Foxtail millet is an important target for genetic transformation among millet crops owing to its close similarity to potential bioenergy grasses. Particle bombardment and Agrobacterium-mediated genetic transformation are important transgenomics approaches, however, poor transformation efficiency makes particle bombardment a least preferred choice. Liu et al. (2009) reported transformation of SiPf40 through particle bombardment in foxtail millet where pROKf40s, pROKf40an and pROKf40i plasmids were used. Agrobacterium-mediated transformation is more widely used but there has been only one report in foxtail millet for improved abiotic stress tolerance. Li et al. (2014) reported transformation of SiARDP, a target gene of SiAREB in foxtail millet and Arabidopsis and found it to play crucial role in drought stress tolerance.

\section{Pearl Millet}

Biolistic method of gene delivery has mostly been used for pearl millet transformation (Ceasar and Ignacimuthu, 2009). The first report on pearl millet transformation through particle bombardment was by Taylor et al. (1991) where plasmid pMON8678 was used for transformation. Later several groups reported on biolistic transformation of this crop with different target tissues and transgenics were raised against fungal pathogens (Ceasar and Ignacimuthu, 2009). However no report on genetically engineered improved abiotic stress tolerant pearl millet has been reported till date. Only recently Agrobacteriummediated transformation using shoot apices have been reported in pearl millet (Jha et al., 2011; Ignacimuthu and Kannan, 2013).

\section{Finger Millet}

The genetic improvement of finger millet through transgenic technology has been limited despite its 
nutritional significance as well as the fact that improved grain yield conferring resistance to other stresses is a priority in this crop. The two earlier reports on finger millet transformation were through biolistic method (Gupta et al., 2001; Latha et al., 2005). Agrobacterium-mediated transformation of finger millet using shoot explants was established by Ceasar and Ignacimuthu (2011). There has been only one report on generation of transgenic finger millet with improved multiple stress tolerance including drought, salinity and oxidative stress (Hema et al., 2014). In this study the tolerance in finger millet was achieved through the stable expression of mannitol1-phosphate dehydrogenase ( $m t l D)$ gene from bacteria.

\section{Gene Silencing}

Gene silencing is an important reverse genetics approach used to determine function of a known gene that leads to altered phenotypes. Insertional mutagenesis (T-DNA insertions or transposable elements insertion) is one of the gene silencing methods which is used to knock out expression of a target mRNA but the process suffers certain limitations as in the case of multigene family members, and thus the process requires considerable analyses for selection of desired genes. Also it has not been possible to achieve targeted gene replacement via homologous recombination in higher plants to date. Recently virus-induced gene silencing (VIGS) through dsRNA has emerged as an important functional genomics tool which is relatively easy and rapid (Baulcombe, 2004). VIGS suppresses target plant gene expression through virus vectors that harbors a target region of the host gene. In general, it does not produce knockout mutants nor does it generate stable RNA interference (RNAi) and can also be carried out in species which are not easy to transform (Scofield and Nelson, 2009). Though several vectors are available for supporting VIGS in crop plants, they have yet not been extensively utilized in millets. Foxtail millet due to its close proximity to several bioenergy grasses has been adopted as a high-throughput platform for VIGS to model gene inhibition outcomes (Doust et al., 2009). Ramanna et al. (2011) have developed VIGS protocol for functional characterization of cell wall related genes in foxtail millet where in Brome mosaic virus was used as the vector (http:// cdm16483.contentdm.oclc.org/cdm/ref/collection/ p15481coll2/id/3763). A VIGS system has also been developed in pearl millet (Turina et al., 1998; van Nugteren et al., 2007). However until now there has been no report on utilization of VIGS for enhancing abiotic stress tolerance in millet crops.

\section{Transcriptomics}

'Transcriptome' refers to the total population of messenger RNAs (mRNAs) in a cell or tissue or organism and the investigation thereof is termed as 'transcriptomics'. Subsequently genome-wide expression profiling studies serve as powerful tools for identifying candidate genes involved in various biological processes and stress regulatory networks. Plants exposed to drought, salinity or temperature extremes or ABA generally undergo cellular dehydration and hence almost half of the genes expressed in all these stresses are common (Reddy et al., 2012). Normally, the abiotic stress responsive genes can broadly be categorized into two classes on the basis of their response in terms of duration, namely early- and late-responsive where early responsive genes respond immediately to stress within a few seconds or minutes, the late responsive ones may take hours, days or even weeks for their expression (Ramanjulu and Bartels, 2002). Hence it is envisaged that the early responsive genes such as protein kinases and TFs are implicated in providing initial protection and regulating gene expression by being themselves directly involved in signal perception, amplification and transduction. While the late responsive genes encode for proteins such as late embryogenesis abundant (LEA) proteins, heat shock proteins (HSPs), reactive oxygen species (ROS) scavengers etc. and are speculated to help in stress adaptation (Bray, 1997; Ramanjulu and Bartels, 2002). Also it has been reported that $11 \%$ of stress-inducible genes are essentially potential TFs supporting the significance of gene regulation in stress adaptation and tolerance (Seki et al., 2002).

The transcriptomic approach per se allows comprehensive analysis and quantification of changes induced by abiotic stresses at whole organism level. 
Among monocots, rice has been extensively investigated for gene expression studies and the results so obtained could also be used for comparative genomics in millets. However, the rice model is likely to be quite diverse from millets in terms of stress response, physiology, architecture and metabolism since physiological processes between $\mathrm{C}_{3}$ and $\mathrm{C}_{4}$ crops are essentially different. Therefore developing a $\mathrm{C}_{4}$ grass model system has become increasingly pertinent in the present scenario. Significant progress in millets research at genetic and genomic levels has been made using model $\mathrm{C}_{4}$ crop foxtail millet (Lata $e t$ $a l .$, 2013) through genome sequencing, macro- and microarray analysis and other high throughput techniques (Lata and Prasad, 2012; Lata et al., 2013). Setaria genome sequence is available for public use at http://www.phytozome.net/foxtailmillet.php. The next generation sequencing platforms have revolutionized scientific research as they allow deciphering sequences of cell transcripts within hours. Hence this approach has the ability to circumvent the problems posed by extremely large genomes such as those of millets.

\section{Foxtail Millet}

Foxtail millet is a naturally drought stress tolerant crop having higher water use efficiency (WUE) as compared to maize, wheat and sorghum (Zhang et al., 2007; Lata et al., 2013). Recently, the whole transcriptome of foxtail millet was analyzed through deep sequencing that led to the identification of drought-responsive 2,824 genes with differential expression patterns, out of which $48.23 \%$ and $51.77 \%$ were up-, down-regulated, respectively (Qi et al., 2013). LEA proteins, dehydrins, HSPs, aquaporins and phosphatase $2 \mathrm{C}$ were the most abundant up-regulated proteins suggesting their possible role in imparting drought tolerance to foxtail millet. Transcript profiling of foxtail millet exposed to drought stress was also carried out by Yin et al. (2014). In this study an Fbox protein was found to be involved drought and ABA response. Setaria genome sequencing project also revealed the presence of 586 'response to water' genes which are predicted to play significant roles in stress response and adaptation (Zhang et al., 2012). Earlier Zhang et al. (2007) identified several drought- induced differentially expressed genes in foxtail millet using suppression subtractive hybridization and cDNA microarray. The expression analysis of these genes indicated that distinct sets of genes are activated in roots and shoots of foxtail millet on drought stress treatment and interestingly majority of them participate in protein degradation pathway. In a similar study, 86 up-regulated genes were identified at $0.5 \mathrm{~h}$ and $6 \mathrm{~h}$ of polyethylene-induced dehydration stress in tolerant foxtail millet cultivar 'Prasad' (Lata et al., 2010). In order to understand the salinity tolerance mechanism, comparative transcriptome analysis of salinity tolerant and sensitive cultivars was carried out by Puranik et al. (2011) wherein a total of 159 differentially expressed transcripts were identified. However first systematic study to identify salt-responsive differentially expressed transcripts was carried out by Jayaraman et al. (2008) where 90 transcript derived fragments were identified using cDNA-AFLP technique in two foxtail millet cultivars, tolerant and sensitive for salinity tolerance. Earlier, Sreenivasulu et al. (2004) identified several differentially expressed transcripts in salt-treated tolerant and sensitive foxtail millet seedlings using a macroarray filter with 711 cDNA spots representing 620 unigenes of a barley EST collection.

Extensive genome-wide investigation and expression profiling studies of various $\mathrm{TF}$ families such as AP2/ERFs, NAC, $\mathrm{C}_{2} \mathrm{H}_{2}$ zinc finger and MYB (Lata et al., 2014; Puranik et al., 2013; Muthamilarasan et al., 2014b; Muthamilarasan et al., 2014c) and stress responsive genes such as WD40, DCL, AGO and RDR polymerases and ALDH (Mishra et al., 2014; Yadav et al., 2014c; Zhu et al., 2014) have also been carried out in foxtail millet for analyzing gene families implicated in stress tolerance, identifying suitable candidate genes and delineating gene regulatory networks and molecular cross talks for abiotic stress responses.

\section{Pearl Millet}

Pearl millet is known for its drought and heat tolerance as it can withstand severe moisture and high temperature stress and can adjust a wide range of soil conditions. It is also being considered as a potential biofuel crop (http://ag.fvsu.edu/index.php/research/ 
bioenergy/). Yet until very recent times, pearl millet received comparatively little attention from the scientific community. Identification and characterization of stress responsive genes and their targets from pearl millet will not only help in understanding stress regulated pathways but will also help in designing strategies for improving stress tolerance/resistance of pearl millet as well as other related crop plants. There has been only one report on transcriptome analysis of pearl millet under abiotic stress conditions (Mishra et al., 2007). A total of 2,494 differentially regulated transcripts in response to drought, salinity and cold stress were identified and the study indicated the existence of a complex gene regulatory network that differentially modulates gene expression under various stresses. Though its large genome size has been a hindrance for sequencing its genome, pearl millet comprehensive transcriptome has been developed by combining together the transcriptome data of three independent research works namely Rajaram et al. (2013), Zeng et al. (2011) and Yves et al., (unpublished; http:// www.ceg.icrisat.org/transcriptome.html). The transcriptome analysis of pearl millet under drought stress using next-generation sequencing (NGS) approach is also under progress and is thought to provide novel insights into gene regulatory networks operating in this naturally stress tolerant crop (Lata et al., unpublished observations).

\section{Finger Millet}

Finger millet is also known for its superior tolerance against various abiotic stresses such as drought and salinity. Rahman et al. (2014) reported the identification of several salinity responsive genes and genotype specific responses from transcriptome analysis of contrasting finger millet genotypes differing for salinity tolerance through mapping and annotation of identified transcripts using rice gene models. In another important study, transcriptome wide identification and validation of calcium sensor gene family in the developing spikes of finger millet was carried out in order to understand their role in calcium accumulation (Singh et al., 2014). Various transcriptomic studies carried out in these three millet crops till date is listed in Table 2.

\section{Proteomics}

The term 'proteome' refers to the entire set of proteins produced or modified by an organism, and 'proteomics' therefore refers to a large-scale analysis of proteins expressed at a given stage or condition in a cell, tissue or organism in order to understand the biology or underlying regulatory mechanism. The existent state of any organism is indicated by its proteome which is essentially a link between its transcriptome and metabolome. As mRNA levels may not be always correlated with protein accumulation and also that proteins tend to act directly on biochemical processes, proteomics approach becomes rather essential in evaluating plant stress responses (Gygi et al., 1999). In recent years, a number of novel approaches have been developed for deeper proteome analyses from particular tissues or subcellular fractions which generally complement the well-established two dimensional electrophoresis (2-DE) technique (Barkla et al., 2003). Post-translationally modified proteins are generally identified using mass spectrometry (MS)based proteomic approaches (Barkla et al., 2003). Despite the advancements in proteomics research, reports on proteomics application to crops are scanty as compared to other biological systems (Reddy et al., 2012). Furthermore, as compared to transcriptome analysis, proteomic analysis in plants in response to various stresses is still very limited (Canovas et al., 2004) with only one study reported in foxtail millet among all millets. Proteomic analysis of 7 day old salt-treated tolerant cv. 'Prasad' seedlings was carried out using two-dimensional electrophoresis which led to the identification of 29 differentially expressed proteins involved in signal transduction, photosynthesis, metabolism and stress response (Veeranagamallaiah et al., 2008). However protein profiling along with SSR and RAPD-PCR of 52 finger millet genotypes has also been reported which was carried out in order to investigate the variation in protein content (Kumar et al., 2012).

\section{Metabolomics}

Genomics, transcriptomics or proteomics have undoubtedly played important role in providing information regarding genotype and complex biological 
Table 2: Details of transcriptomic studies carried out in foxtail millet, pearl millet and finger millet under different abiotic stresses

\begin{tabular}{|c|c|c|c|}
\hline Crop & Strategy & Nature of study & Reference \\
\hline \multirow[t]{6}{*}{ Foxtail millet } & Illumina HiSeq 2000 platform & $\begin{array}{l}\text { Transcriptome analysis of 14-day old var. Yugu } 1 \\
\text { seedlings exposed to } 20 \% \text { Polyethylene glycol (PEG) } \\
6000 \text { stress at different time points } \\
\text { Tissue: Shoot }\end{array}$ & Qi et al., 2013 \\
\hline & $\begin{array}{l}\text { Suppression subtractive } \\
\text { hybridization }(\mathrm{SSH}) \text { and dot } \\
\text { blot array }\end{array}$ & $\begin{array}{l}\text { Comparative transcriptome analysis of contrasting foxtail } \\
\text { millet cultivars under short-term salinity stress }(250 \mathrm{mM} \\
\mathrm{NaCl} ; 6 \mathrm{~h}) \\
\text { Tissue: Whole seedling }\end{array}$ & Puranik et al., 2011 \\
\hline & SSH and dot blot array & $\begin{array}{l}\text { Comparative transcriptome analysis of a tolerant foxtail } \\
\text { millet cv. Prasad at early }(0.5 \mathrm{~h}) \text { and late }(6 \mathrm{~h}) \text { time points of } \\
20 \% \text { PEG-induced drought stress } \\
\text { Tissue : Whole seedling }\end{array}$ & Lata et al., 2010 \\
\hline & cDNA-AFLP & $\begin{array}{l}\text { Comparative cDNA-AFLP analysis between contrasting } \\
\text { foxtail millet cultivars differing for salinity tolerance } \\
\text { Tissue: Leaves }\end{array}$ & Jayaraman et al., 2008 \\
\hline & SSH and microarray & $\begin{array}{l}\text { Comprehensive transcriptome analysis of a tolerant } \\
\text { foxtail millet cv. Mar1 under drought stress ( } 20 \% \text { PEG) } \\
\text { Tissue: Root and shoot }\end{array}$ & Zhang et al., 2007 \\
\hline & cDNA macro array & $\begin{array}{l}\text { A barley cDNA macroarray used for monitoring transcript } \\
\text { abundance in contrasting foxtail millet seedlings exposed } \\
\text { to long-term high salinity stress } \\
\text { Tissue: Whole seedling }\end{array}$ & Sreenivasulu et al., 2004 \\
\hline \multirow[t]{2}{*}{ Pearl millet } & $\begin{array}{l}\text { Illumina MiSeq platform } \\
\text { (2X300 bp chemistry) }\end{array}$ & $\begin{array}{l}\text { Comparative trancriptome analysis of two contrasting } \\
\text { pearl millet genotypes (parents of a mapping population) } \\
\text { differing for terminal drought tolerance } \\
\text { Tissue: Leaves }\end{array}$ & Lata et al. unpublished \\
\hline & Subtracted cDNA library & $\begin{array}{l}\text { Identification of differentially regulated transcripts from } \\
\text { a drought tolerant parental line under salinity, drought } \\
\text { and cold stresses } \\
\text { Tissue: Leaves and roots }\end{array}$ & Mishra et al., 2007 \\
\hline \multirow[t]{3}{*}{ Finger millet } & Illumina HiSeq 2000 platform & $\begin{array}{l}\text { Transcriptome sequencing of two contrasting finger } \\
\text { millet genotypes } \\
\text { Tissue: Four stages of developing spikes }\end{array}$ & Kumar et al., 2014 \\
\hline & Illumina HiSeq 2000 platform & $\begin{array}{l}\text { Transcriptome sequencing of two finger millet genotypes } \\
\text { differing in grain calcium content } \\
\text { Tissue: Spikes }\end{array}$ & Singh et al., 2014 \\
\hline & IonProton platform & $\begin{array}{l}\text { Sequencing of salinity responsive leaf trancriptome of } \\
\text { two contrasting finger millet genotypes } \\
\text { Tissue: Leaves }\end{array}$ & Rahman et al., 2014 \\
\hline
\end{tabular}

processes but still are insufficient in discerning phenotype which is ultimately determined by a cell's metabolite. Therefore among all 'omics' sciences, 'metabolomics' is one of the newest. 'Metabolome' in particular refers to the complete set of low molecular weight compounds present in a sample which are either substrates or byproducts of enzymatic reactions and tend to have a direct effect on phenotype of a cell/tissue/organism. Metabolomics thus aims at determining a sample's metabolites profile at specific time or stage or environmental conditions and hence provides a straight functional statement of an organism's physiological condition. Further, transcriptome or proteome do not necessarily relate 
to changes in the cell metabolome, thus emphasizing the relevance of metabolomics in the functional genomics era (Sumner et al., 2003). Various conceptual approaches in metabolomics include target analysis, and metabolite profiling and fingerprinting that can be eventually used for several large-scale applications such as phenotyping transgenics, gene function determination, substantial equivalence testing, and monitoring stress responses. Metabolomics is thus considered to bridge the gap between genotype and phenotype. Therefore an integrated analysis of transcriptome, proteome, and metabolome is essential to have a complete understanding of both gene function and molecular events regulating complex biological processes. Most of the metabolomics work has been carried out in model plants and staple cereals with no report of metabolic profiling in any of the major millet crops. There is only one report of metabolic profiling in three varieties of proso millet using gas-chromatography-time-of-flight mass spectrometry (GC-TOFMS) to determine diversity among primary metabolites and phenolic acids (Kim et al., 2013).

\section{Phenomics}

'Phenomics' is an equally important 'omics' technology critical for advanced genomics. The term phenomics refer to measurement of 'phenomes' or more precisely physical and biochemical traits of an organism as they tend to change under the influence of environmental stresses or genetic mutation. In order to harness the wealth of information generated by genomics platform has to be precisely linked to the phenotype. Infact unless phenotypic expression of plants displaying any level of genomic/trancriptomic/ proteomic/or metabolic profile is not accurately characterized or understood, calling any of the above approaches successful will be wrong. A large gap exists between the knowledge of genotype and phenotype or in other words linkage between genotype and phenotype is rather illusive (Furbank and Tester, 2011). Indeed high throughput physiology and phenotyping has emerged as a new bottleneck in plant breeding and stress biology (Yang et al., 2013). Therefore it is necessary to formulate certain basic principles for phenomics characterization for detailed analyses of any abiotic stress in crop plants. Rigorous phenotyping layout in the form of dry-down technique for progressive water stress has been developed in pearl millet in addition to WUE and drought resistance index (Vadez et al., 2012). Other than these tillering, flowering time and rooting ability have also been the primary criteria for phenotyping in pearl millet (Vadez et al., 2012). In foxtail millet, LP has been established as an important marker for oxidative stress (Lata $e t$ al., 2011b). Though foxtail millet also needs development of efficient phenotyping methods both high throughput and manual for designing effective breeding strategies considering its importance as an excellent model system for studying biofuel crops.

\section{Bioinformatics and Systems Biology Approaches for Omics Research}

Understanding complex regulatory networks and the biological principles governing abiotic stress responses and tolerance in plants require sound knowledge of genome-scale responses at various developmental stages as well as against different environmental stimuli. Mostly expression datasets are available for model plants such as Arabidopsis and rice. Mining such datasets usually depends on various clustering algorithms that find groups or clusters of coexpressed genes that are hypothesized to be co-regulated under same internal or external stimuli by similar set of transcription factors and hence tend to form a transcriptional sub-network (Moreno-Risueno et al., 2010). This principle can be used to infer regulatory hierarchies of gene expression across different species and genera. Further analysis of more complex and large-scale gene expression data require additional sophisticated approaches wherein bioinformatics tools play an important role. Using advanced bioinformatics tools and pipelines genome-scale data from various time-course experiments under diverse environmental conditions can easily be processed to identify and infer significant patterns coupled with specific cis-elements and regulatory such as TFs as well as other stress/ stimuli-specific genes, and thus help in reconstructing regulatory and metabolic networks involving them and their regulatory interactions (Ma et al., 2007; MorenoRisueno et al., 2010). 
As far as proteomics and metabolomics are concerned, proteomics uses mass spectrometry (MS) based studies for protein profiling while metabolomics uses MS or nuclear magnetic resonance (NMR) based studies for metabolite profiling of particular cells, tissues, organelles/organs or whole plant. The data obtained from these two studies can be correlated with transcriptome profiles to decipher various signaling and metabolic networks for a particular internal or environmental cue. Metabolome studies in particular have the potential to elucidate biochemical networks, however integration of unknown metabolites into such networks is not possible by simply correlating analyses as in case of transcriptional or proteome networks. In such cases an integration of QTL analysis and qualitative metabolite profiling may be helpful in establishing de novo models on biochemical networks involving complex plant responses (Rowe et al., 2008). A description of largescale omics data integration for the reconstruction and analysis of biological networks and pathways is shown in Fig. 3. Until now not much work has been done using systems biology approaches for deciphering regulatory networks in millet crops, and therefore it is critical to make rigorous efforts in this direction by researchers worldwide to understand the biological networks operating in these otherwise nutritionally and economically important orphan crops.

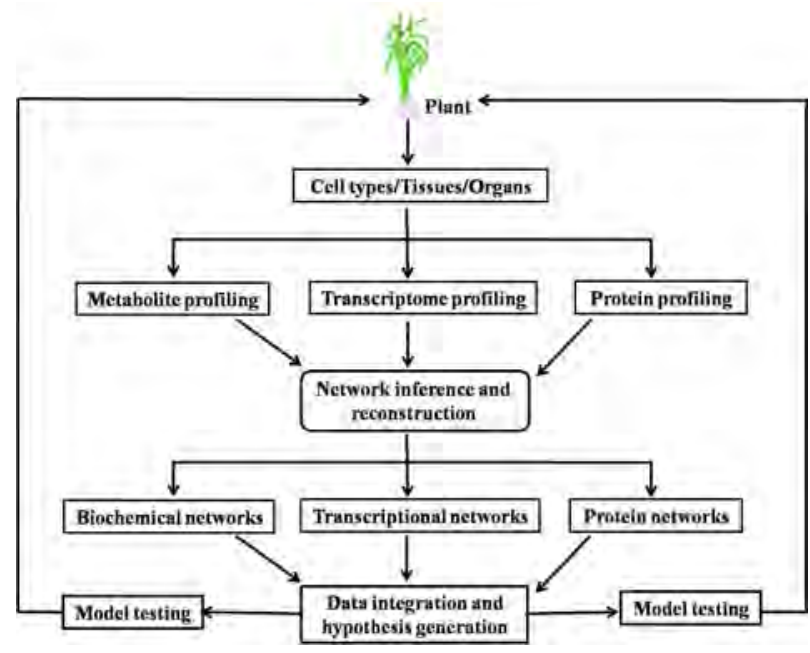

Fig. 3: A depiction of large-scale omics data integration for the reconstruction and analysis of biological networks and pathways

\section{Conclusion and Future Perspectives}

In recent years, molecular biology and biotechnology has appeared as a promising tool for overcoming stresses in plants, however, to date the progress has been limited in millet crops. Omics approaches have proved to be the most straightforward and potential biotechnological applications for improving abiotic stress tolerance in millets which lack proper resources for conventional plant breeding. Nevertheless successful application of omics for abiotic stress tolerance depends on the knowledge of stress response at molecular level. Therefore, with the availability of foxtail millet genome sequence, and ongoing genomics program in pearl millet and finger millet, application of omics for abiotic stress research in millets will be manifold. The current and up-coming high-throughput sequencing platforms are able to provide a wide variety of sequencing applications to researchers including identification of small RNAs, SNPs and molecular markers discovery. NGS approaches together with genome-wide expression profiling studies will be able to overcome the problems put forward by large genomes particularly those like millets. As compared to genomics and transcriptomics, proteomics and metabolomics studies still lag behind in millet crops. However with the advancements in high-throughput proteomics and metabolomics approaches such as flow injection - time-of-flight mass spectrometry etc., as well as an integration of various omics strategies will revolutionize the study of complex biological systems such as those of millets. It will not only help in large-scale identification of genes/proteins and metabolites involved in multiple molecular and signaling networks but also enhance our fundamental understandings on the molecular basis of abiotic stress tolerance in these crops. Hence, it is essential to extensively carry out these kinds of studies in millets for overcoming abiotic constraints. A concerted effort including all omics will be an important step towards deciphering abiotic stress tolerance mechanism in millets which can further be utilized for MAS or conventional breeding. Mapping of abiotic stress QTLs in millet crops is still in an early stage with no report on gene pyramiding till date. Availability of more number of ESTs and genome sequences will not only play important role in translating the knowledge in 
other millet crops and grasses but also in QTL mapping and other breeding strategies. Genetic engineering of millet crops for improved abiotic stress tolerance should also be a focal point of research which will only be possible by identification of more number of potential candidate genes. Besides it is also important to have a careful and meaningful phenotyping for understanding the mechanisms of stress adaptation before identifying and tagging genes thought to be responsible for such mechanisms. Nevertheless current advances in omics technologies together with advances in transgenic technology and MAS will

\section{References}

Agarwal PK, Agarwal P, Jain P, Jha B, Reddy MK and Sopory SK (2007) Constitutive overexpression of a stress-inducible small GTP-binding protein PgRab7 from Pennisetum glaucum enhances abiotic stress tolerance in transgenic tobacco Plant Cell Rep 27 105-115

Ahuja I, de Vos RCH, Bones AM and Hall RD (2010) Plant molecular stress responses face climate change Trends Plant Sci 15 1360-1385

Allouis A, Qi X, Lineup S, Gale MD and Devos KM (2001) Construction of a BAC library of pearl millet, Pennisetum glaucum Theor Appl Genet 102 1200-1205

Alvarez S, Marsh EL, Schroeder SG and Schachtman DP (2008) Metabolomic and proteomic changes in the xylem sap of maize under drought Plant Cell Environ 31 325-340

Arya L, Verma M, Gupta VK and Karihaloo JL (2009) Development of EST-SSRs in finger millet (Eleusine coracana ssp coracana) and their transferability to pearl millet (Pennisetum glaucum) J Plant Biochem Biotechnol 18 97-100

Babu BK, Dinesh P, Agrawal PK, Sood S, Chandrashekara C, Bhatt JC and Kumar A (2014) Comparative genomics and association mapping approaches for blast resistant genes in finger millet using SSRs PLOS ONE 9 e99182

Bai H, Cao Y, Quan J, Dong L, Li Z, Zhu Y, Zhu L, Dong Z and Li D (2013) Identifying the genome-wide sequence variations and developing new molecular markers for genetics research by re-sequencing a Landrace cultivar of foxtail millet PLOS ONE $\mathbf{8}$ e 73514

Barkla BJ, Castellanos-Cervantes T, de Leo’ JLD, Matros A, Mock H-P, Perez-Alfocea F, Salekdeh GH, Witzel K and Zörb C (2013) Elucidation of salt stress defense and prove useful in improving the present scenario and it will indeed be possible to target all millet crops for genetic improvement.

\section{Acknowledgements}

I acknowledge the INSPIRE Faculty Award [IFA11LSPA-01] from Department of Science \& Technology (DST), GoI, New Delhi. I am also thankful to Dr. Manoj Prasad (Scientist V, National Institute of Plant Genome Research, New Delhi) for his continuous support and encouragement.

tolerance mechanisms of crop plants using proteomicsCurrent achievements and perspectives Proteomics 13 1885-1900

Baulcombe D (2004) RNA silencing in plants Nature 431 356363

Bennetzen JL, Schmutz J, Wang H, Percifield R, Hawkins J, Pontaroli AC, Estep M, Feng L, Vaughn JN, Grimwood J, Jenkins J, Barry K, Lindquist E, Hellsten U, Deshpande S, Wang X, Wu X, Mitros T, Triplett J, Yang X, Ye CY, Mauro-Herrera M, Wang L, Li P, Sharma M, Sharma R, Ronald PC, Panaud O, Kellogg EA, Brutnell TP, Doust AN, Tuskan GA, Rokhsar D and Devos KM (2012) Reference genome sequence of the model plant Setaria Nature Biotechnol 30 555-561

Bertin I, Zhu JH and Gale MD (2005) SSCP-SNP in pearl milleta new marker system for comparative genetics Theor Appl Genet 1101467-1472

Bidinger FR, Nepolean T, Hash CT, Yadav RS and Howarth CJ (2007) Quantitative trait loci for grain yield in pearl millet under variable post flowering moisture conditions Crop Sci 47 969-980

Bidinger FR, Serraj R, Rizvi SMH, Howarth CJ, Yadav RS and Hash CT (2005) Field evaluation of drought tolerance QTL effects on phenotype and adaptation in pearl millet [Pennisetum glaucum (L.) R.Br.] topcross hybrids Field Crops Res 94 14-32

Bokhari SA, Wan XY, Yang YW, Zhou L, Tang WL and Liu JY (2007) Proteomic response of rice seedling leaves to elevated $\mathrm{CO}_{2}$ levels J Proteome Res 6 4624-4633

Bonthala VS, Muthamilarasan M, Roy R and Prasad M (2014) FmTFDb: A foxtail millet transcription factors database for expediting functional genomics in millets $\mathrm{Mol}$ Biol Rep 
doi: 10.1007/s11033-014-3574-y

Bray EA (1997) Plant responses to water deficit Trends Plant Sci 2 48-54

Bray EA, Bailey-Serres J and Weretilnyk E (2000) Responses to abiotic stresses. In: Biochemistry and Molecular Biology of Plants (Eds: Gruissem W, Buchannan B and Jones R), pp 1158-1249, American Society of Plant Physiologists, Rockville, MD

Budak H, Pedraza F, Baenziger PS, Cregan PB and Dweikat I (2003) Development and utilization of SSR to estimate genetic diversity in a collection of pearl millet germplasm Crop Sci 43 2284-2290

Canovas F, Dumas-Gaudot E, Recorbet G, Jorrin J, Mock H-P and Rossignol M (2004) Plant proteome analysis Proteomics 4 285-298

Caruso G, Cavaliere C, Foglia P, Gubbiotti R, Samperi R and Laganà A (2009) Analysis of drought responsive proteins in wheat (Triticum durum) by 2D-PAGE and MALDITOF mass spectrometry Plant Sci 177 570-576

Ceasar SA and Ignacimuthu S (2009) Genetic engineering of millets: current status and future prospects Biotechnol Lett $\mathbf{3 1}$ 779-788

Ceasar SA and Ignacimuthu S (2011) Agrobacterium-mediated transformation of finger millet (Eleusine coracana (L.) Gaertn.) using shoot apex explants Plant Cell Rep 30 17591770

Chinnusamy V, Schumaker K and Zhu J-K (2004) Molecular genetic perspectives on cross-talk and specificity in abiotic stress signalling in plants $J$ Exp Bot 55 225-236

Degenkolbe T, Do PT, Zuther E, Repsilber D, Walther D, Hincha DK and Köhl KI (2009) Expression profiling of rice cultivars differing in their tolerance to long-term drought stress Plant Mol Biol 69 133-153

Devos KM, Pittaway TS, Busso CS, Gale MD, Witcombe JR and Hash CT (1995) Molecular tools for the pearl millet nuclear genome Int Sorghum Millets Newslett 36 64-66

Devos KM, Pittaway TS, Reynolds A and Gale MD (2000) Comparative mapping reveals a complex relationship between the pearl millet and those of foxtail millet and rice Theor Appl Genet 100 190-198

Devos KM, Wang ZM, Beales J, Sasaki T and Gale MD (1998) Comparative genetic maps of foxtail millet (Setaria italica) and rice (Oryza sativa) Theor Appl Genet 96 63-68

Dida MM, Srinivasachary, Ramakrishnan S, Bennetzen JL, Gale MD and Devos KM (2007) The genetic map of finger millet, Eleusine coracana Theor Appl Genet 114 321-332

Dida MM, Waneyara N, Dunn DLH, Bennetzen JL and Devos KM (2008) Population structure and diversity in Finger millet (Eleusine coracana) germplasm Tropical Plant Biol 1 131-141

Dita MA, Rispail N, Prats E, Rubiales D and Singh KB (2006) Biotechnology approaches to overcome biotic and abiotic stress constraints in legumes Euphytica 147 1-24

Doust AN, Kellog EZ, Devos KM and Bennetzen JL (2009) Foxtail millet: A sequence driven grass model system Plant Physiol 149 137-141

Dwivedi S, Upadhyaya H, Senthilvel S, Hash C, Fukunaga K, Diao X, Santra D, Baltensperger D and Prasad M (2012) Millets: Genetic and Genomic Resources. In: Plant Breeding Reviews (Ed: Janick J) 35 pp 247-375, John Wiley \& Sons, USA

Furbank RT and Tester M (2011) Phenomics - technologies to relieve the phenotyping bottleneck Trends Plant Sci 16 635-644

Ginzberg I, Barel G, Ophir R, Tzin E, Tanami Z, Muddarangappa T, de Jong W and Fogelman E (2009) Transcriptomic profiling of heat-stress response in potato periderm $J$ Exp Bot 60 4411-4421

Glazebrook J (2005) Contrasting mechanisms of defense against biotrophic and necrotrophic pathogens Annu Rev Phytopathol 43 205-227

Gulia SK, Hash CT, Thakur RP, Breese WA and Sangwan RS (2007) Mapping new QTLs for improvement of downy mildew resistance in pearl millet. In: Crop Production in Stress Environments: Genetic and Management Options (Eds: Singh DP, Tomar VS, Behl RK, Upadhyaya SD, Bhale MS, Khare B) pp 373-386, Agrobios International, Jodhpur, Rajasthan, India

Gupta P, Raghuvanshi S and Tyagi AK (2001) Assessment of the efficiency of various gene promoters via biolistics in leaf and regenerating seed callus of millets, Eleusine coracana and Echinochloa crusgalli Plant Biotechnol 18 275-282

Gupta S, Kumari K, Das J, Lata C, Puranik S and Prasad M (2011) Development and utilization of novel intron length polymorphic markers in foxtail millet [Setaria italica $(\mathrm{L}$. P. Beauv.] Genome 54 586-602

Gupta S, Kumari K, Muthamilarasan M, Parida SK and Prasad M (2014) Population structure and association mapping of yield contributing agronomic traits in foxtail millet Plant Cell Rep 33 881-893

Gupta S, Kumari K, Muthamilarasan M, Subramanian A and Prasad M (2013) Development and utilization of novel SSRs in foxtail millet [Setaria italica (L.) P. Beauv.] Plant Breed 132 367-374

Gupta S, Kumari K, Sahu PP, Vidapu S and Prasad M (2012) Sequence based novel genomic microsatellite markers for 
robust genotyping purposes in foxtail millet [Setaria italica (L.) P. Beauv.] Plant Cell Rep 31 323-337

Gygi SP, Rochon Y, Franza BR and Aebersold R (1999) Correlation between protein and mRNA abundance in yeast $\mathrm{Mol} \mathrm{Cell}$ Biol 19 1720-1730

Hema R, Vemanna RS, Sreeramulu S, Reddy CP, Senthil-Kumar $M$ and Udayakumar M (2014) Stable expression of mtlD gene imparts multiple stress tolerance in finger millet $P L o S$ ONE 9 e 99110

Heng L, Chih C, Song C and Chang K (2011) Development of simple sequence repeats (SSR) markers in Setaria italica (Poaceae) and cross-amplification in related species Int $J$ Mol Sci 12 7835-7845

Ignacimuthu S and Kannan P (2013) Agrobacterium-mediated transformation of pearl millet (Pennisetum typhoides $(\mathrm{L}$. R. Br.) for fungal resistance Asian J Plant Sci 12 97-108

Jayaraman A, Puranik S, Rai NK, Vidapu S, Sahu PP, Lata C and Prasad M (2008) cDNA-AFLP analysis reveals differential gene expression in response to salt stress in foxtail millet (Setaria italica L.) Mol Biotechnol 40 241251

Jha P, Shashi, Rustagi A, Agnihotri PK, Kulkarni VM and Bhat V (2011) Efficient Agrobacterium-mediated transformation of Pennisetum glaucum (L.) R. Br. using shoot apices as explant source Plant Cell Tiss Organ Cult 107 501-512

Jia G, Huang X, Zhi H, Zhao Y, Zhao Q, Li W, Chai Y, Yang L, Liu K, Lu H, Zhu C, Lu Y, Zhou C, Fan D, Weng Q, Guo Y, Huang T, Zhang L, Lu T, Feng Q, Hao H, Liu H, Lu P, Zhang N, Li Y, Guo E, Wang S, Wang S, Liu J, Zhang W, Chen G, Zhang B, Li W, Wang Y, Li H, Zhao B, Li J, Diao $X$ and Han B (2013) A haplotype map of genomic variations and genome-wide association studies of agronomic traits in foxtail millet (Setaria italica) Nat Genet 45 957-961

Jia X, Zhang Z, Liu Y, Zhang C, Shi Y, Song Y, Wang T and Li Y (2009) Development and genetic mapping of SSR markers in foxtail millet [Setaria italica (L.) P. Beauv.] Theor Appl Genet 118 821-829

Jia XP, Shi YS, Song YC, Wang YG, Wang TY and Li Y (2007) Development of EST-SSR in foxtail millet (Setaria italica) Genet Res Crop Evol 54 233-236

Jones ES, Breese WA, Liu CJ, Singh SD, Shaw DS and Witcombe JR (2002) Mapping quantitative trait loci for downy mildew resistance in pearlmillet: field and glass house screens detect the same QTL Crop Sci 42 1316-1323

Jones ES, Liu CJ, Gale MD, Hash CT and Witcombe JR (1995) Mapping quantitative trait loci for downy mildew resistance in pearl millet Theor Appl Genet 91 448-456

Khan Y, Yadav A, Suresh BV, Muthamilarasan M, Yadav CB and
Prasad M (2014) Comprehensive genome-wide identification and expression profiling of foxtail millet [Setaria italica (L.)] miRNAs in response to abiotic stress and development of miRNA database Plant Cell Tiss Organ Cult 118 279-292

Kholová J, Hash CT, Kumar PL, Yadav RS, Kocová M and Vadez V (2010) Terminal drought-tolerant pearl millet [Pennisetum glaucum (L.) R. Br.] have high leaf ABA and limit transpiration at high vapour pressure deficit $J$ Exp Bot 62 1431-1440

Kholová J, Nepolean T, Hash CT, Supriya A, Rajaram V, Senthilvel S, Kakkera A, Yadav RS and Vadez V (2012) Water saving traits co-map with a major terminal drought tolerance quantitative trait locus in pearl millet (Pennisetum glaucum (L.) R. Br.) Mol Breed 30 1337-1353

Kim JK, Park S-Y, Yeo Y, Cho HS, Kim YB, Bae H, Park CH, Lee J-H and Park SU (2013) Metabolic profiling of millet (Panicum miliaceum) using gas chromatography-time-offlight mass spectrometry (GC-TOFMS) for quality assessment Plant Omics $J$ 6: 73-78

Kissoudis C, van de Wiel C, Visser RGF and van der Linden G (2014) Enhancing crop resilience to combined abiotic and biotic stress through the dissection of physiological and molecular crosstalk Frontiers Plant Sci doi: 10.3389/ fpls.2014.00207

Kothari SL, Kumar S, Vishnoi RK, Kothari SL and Watanabe KN (2005) Applications of biotechnology for improvement of millet crops: review of progress and future prospects Plant Biotechnol 22 81-88

Kumar A, Sharma N, Panwar P and Gupta AK (2012) Use of SSR, RAPD markers and protein profiles based analysis to differentiate Eleusine coracana genotypes differing in their protein content Mol Bio Rep 39 4949-4960

Kumar A, Gaur VS, Goel A and Gupta AK (2014) De novo assembly and characterization of developing spikes transcriptome of finger millet (Eleusine coracana): a minor crop having nutraceutical properties Plant Mol Biol Rep DOI 10.1007/s11105-014-0802-5

Kumari K, Muthamilarasan M, Misra G, Gupta S, Subramanian A, Parida SK, Chattopadhyay D and Prasad M (2013) Development of eSSR-markers in Setaria italica and their applicability in studying genetic diversity, crosstransferability and comparative mapping in millet and nonmillet species PLoS ONE 8 e67742

Lata C, Bhutty S, Bahadur RP, Majee M and Prasad M (2011a) Association of an SNP in a novel DREB2-like gene SiDREB2 with stress tolerance in foxtail millet [Setaria italica (L.)] J Exp Bot 62 3387-3401 
Lata C, Gupta S and Prasad M (2013) Foxtail millet: a model crop for genetic and genomic studies in bioenergy grasses Crit Rev Biotechnol 33 328-343

Lata C, Jha S, Dixit V, Sreenivasulu N and Prasad M (2011b) Differential antioxidative responses to dehydrationinduced oxidative stress in core set of foxtail millet cultivars [Setaria italica (L.)] Protoplasma 248 817-828

Lata C, Mishra AK, Muthamilarasan M, Bonthala VS, Khan Y and Prasad M (2014) Genome-wide investigation and expression profiling of AP2/ERF transcription factor superfamily in foxtail millet (Setaria italica L.) PLOS ONE 9 e113092

Lata C and Prasad M (2013a) Setaria genome sequencing: an overview J Plant Biochem Biotechnol 22 257-260

Lata C and Prasad M (2013b) Association of an allele-specific marker with dehydration stress tolerance in foxtail millet suggests SiDREB2 to be an important QTL J Plant Biochem Biotechnol 23 119-122

Lata C, Sahu PP and Prasad M (2010) Comparative transcriptome analysis of differentially expressed genes in foxtail millet (Setaria italica L.) during dehydration stress Biochem Biophy Res Commun 393 720-727

Lata C and Prasad M (2012) Validation of an allele-specific marker associated with dehydration stress tolerance in a core set of foxtail millet accessions Plant Breed 132 496-499

Latha MA, Venkateswara Rao K and Dashavantha Reddy V (2005) Production of transgenic plants resistant to leaf blast disease in finger millet (Eleusine coracana (L.) Gaertn.) Plant Sci 169 657-667

Le Thierry d'Ennequin M, Panaud O, Toupance B and Sarr A (2000) Assessment of genetic relationship between Setaria italica and its wild relative $S$. viridis using AFLP markers Theor Appl Genet 100 1061-1066

Li C, Yue J, Wu X, Xu C and Yu J (2014) An ABA-responsive DRE-binding protein gene from Setaria italica, SiARDP, the target gene of SiAREB, plays a critical role under drought stress J Exp Bot doi:10.1093/jxb/eru302

Li W, Zhi H, Wang Y-F, Li H-Q and Diao X (2012) Assessment of genetic relationship of foxtail millet with its wild ancestor and close relatives by ISSR markers J Integr Agric 11 556566

Liu CJ, Witcombe JR, Pittaway TS, Nash M, Hash CT, Busso CS and Gale MD (1994) An RFLP- based genetic map of pearl millet (Pennisetum glaucum) Theor Appl Genet $\mathbf{8 9}$ 481-487

Liu Y, Feng X, Xu Y, Yu J, Ao G, Peng Z and Zhao Q (2009) Overexpression of millet ZIP-like gene (SiPf40) affects lateral bud outgrowth in tobacco and millet Plant Physiol

\section{Biochem 47 1051-1060}

López MA, Bannenberg G and Castresana C (2008) Controlling hormone signaling is a plant and pathogen challenge for growth and survival Curr Opin Plant Biol 11 420-427

Ma S, Gong Q and Bohnert HJ (2007) An Arabidopsis gene network based on the graphical Gaussian model Genome Res 17 1614-1625

Mariac C, Luong V, Kapran I, Mamadou A, Sagnard F, Deu M, Chantereau J, Gerard B, Ndjeunga J, Bezancon G and Pham J-L, Vigouroux Y (2006) Diversity of wild and cultivated pearl millet accessions (Pennisetum glaucum [L.] R. Br.) in Niger assessed by microsatellite markers Theor Appl Genet 114 49-58

Mauro-Herrera M, Wang X, Barbier H, Brutnell TP, Devos KM and Doust AN (2013) Genetic control and comparative genomic analysis of flowering time in Setaria (Poaceae) G3 (Bethesda) 3 283-295

Mishra AK, Muthamilarasan M, Khan Y, Parida SK and Prasad M (2013) Genome-wide investigation and expression analyses of WD40 protein family in the model plant foxtail millet (Setaria italica L.) PLoS ONE 9 e86852

Mishra RN, Reddy PS, Nair S, Markandeya G, Reddy AR, Sopory SK and Reddy MK (2007) Isolation and characterization of expressed sequence tags (ESTs) from subtracted cDNA libraries of Pennisetum glaucum seedlings Plant Mol Biol 64 713-732

Moreno-Risueno MA, Busch W and Benfey PN (2010) Omics meet networks - using systems approaches to infer regulatory networks in plants Curr Opin Plant Biol 13 126-131

Morgan RN, Wilson JP, Hanna WW and Ozias-Akins P (1998) Molecular markers for rust and pyricularia leaf spot disease resistance in pearl millet Theor Appl Genet 96 413-420

Muthamilarasan M, Theriappan P and Prasad M (2013) Recent advances in crop genomics for ensuring food security $\mathrm{Curr}$ Sci 105 155-158

Muthamilarasan M, Venkata Suresh B, Pandey G, Kumari K, Parida SK and Prasad M (2014a) Development of 5123 intron-length polymorphic markers for large-scale genotyping applications in foxtail millet DNA Res 21 4152

Muthamilarasan M, Bonthala VS, Mishra AK, Khandelwal R, Khan Y, Roy R and Prasad M (2014b) $\mathrm{C}_{2} \mathrm{H}_{2}$-type of zinc finger transcription factors in foxtail millet define response to abiotic stresses Funct Integr Genomics doi:10.1007/ s10142-014-0383-2

Muthamilarasan M, Khandelwal R, Yadav CB, Bonthala VS, Khan Y and Prasad M (2014c) Identification and molecular 
characterization of MYB transcription factor superfamily in C4 model plant foxtail millet (Setaria italica L.) PLoS ONE 9 e 109920

Muthamilarasan M and Prasad M (2014) Advances in Setaria genomics for genetic improvement of cereals and bioenergy grasses Theor Appl Genet doi:10.1007/s00122-014-23993

Nepolean T, Blümmel M, Bhasker Raj AG, Rajaram V, Senthilvel S and Hash CT (2006) QTLs controlling yield and stover quality traits in pearl millet Int Sorghum Millets Newslett 47 149-152

Nirgude M, Babu BK, Shambhavi Y, Singh UM, Upadhyaya HD and Kumar A (2014) Development and molecular characterization of genic molecular markers for grain protein and calcium content in finger millet (Eleusine coracana (L.) Gaert.) Mol Biol Rep 41 1189-1200

Nnaemeka OO (2009) Development of microsatellite markers for genetic characterization of a core subset of foxtail millet (Setaria italica) and finger millet (Eleusine coracana) germplasm MS thesis, University of Hohenheim, Germany

Pandey G, Misra G, Kumari K, Gupta S, Parida SK, Chattopadhyay D and Prasad M (2013) Genome-wide development and use of microsatellite markers for largescale genotyping applications in foxtail millet [Setaria italica (L.)] DNA Res 20 197-207

Panwar P, Jha AK, Pandey PK, Arun K Gupta and Anil Kumar (2011) Functional markers based molecular characterization and cloning of resistance gene analogs encoding NBS-LRR disease resistance proteins in finger millet (Eleusine coracana) Mol Biol Rep 38 427-3436

Panwar P, Saini RK, Sharma N, Yadav D and Kumar A (2010) Efficiency of RAPD, SSR and cytochrome P450 gene based markers in accessing genetic variability amongst finger millet (Eleusine coracana) accessions Mol Biol Rep 37 4075-82

Prasada Rao KE and de Wet JMJ (1997) Small millets. In: Biodiversity in Trust (Eds: Fuccilo D, Sears L and Stapleton P) pp 259-272, Cambridge University Press

Puranik S, Jha S, Srivastava PS, Sreenivasulu N and Prasad M (2011) Comparative transcriptome analysis of contrasting foxtail millet cultivars in response to short-term salinity stress J Plant Physiol 168 280-287

Puranik S, Sahu PP, Mandal SN, Venkata Suresh B, Parida SK and Prasad M (2013) Comprehensive genome-wide survey, genomic constitution and expression profiling of the NAC transcription factor family in foxtail millet (Setaria italica L.) PLoS ONE 8 e64594

Qi X, Lindup S, Pittaway TS, Allouis S, Gale MD and Devos
KM (2001) Development of simple sequence repeat markers from bacterial artificial chromosomes without subcloning Biotechniques 31 358-362

Qi X, Pittaway TS, Lindup S, Liu H, Waterman E, Padi FK, Hash CT, Zhu J, Gale MD and Devos KM (2004) An integrated genetic map and a new set of simple sequence repeat markers for pearl millet, Pennisetum glaucum Theor Appl Genet 109 1485-1493

Qi X, Xie S, Liu Y, Yi F and Yu J (2013) Genome-wide annotation of genes and noncoding RNAs of foxtail millet in response to simulated drought stress by deep sequencing Plant Mol Biol 83 459-473

Rahman H, Jagadeeshselvam N, Valarmathi R, Sachin B, Sasikala R, Senthil N, Sudhakar D, Robin S and Muthurajan R (2014) Transcriptome analysis of salinity responsiveness in contrasting genotypes of finger millet (Eleusine coracana L.) through RNA-sequencing Plant Mol Biol 85 485-503

Rajaram V, Nepolean T, Senthilvel S, Varshney RK, Vadez V, Srivastava RK, Shah TM, Supriya A, Kumar S, Kumari BS, Bhanuprakash A, Narasu ML, Riera-Lizarazu O and Hash CT (2013) Pearl millet [Pennisetum glaucum (L.) R. Br.] consensus linkage map constructed using four RIL mapping populations and newly developed EST-SSRs BMC Genomics 14159

Ramanjulu S and Bartels D (2002) Drought- and desiccationinduced modulation of gene expression in plants Plant Cell Environ 25 141-151

Ramegowda V, Senthil-Kumar M, Nataraja KN, Reddy MK, Mysore KS and Udayakumar M (2012) Expression of a finger millet transcription factor, EcNAC1, in tobacco confers abiotic stress-tolerance PLOS ONE 7 e40397

Reddy AR, Chaitany, KV and Vivekanandan M (2004) Drought induced responses of photosynthesis and antioxidant metabolism in higher plants J Plant Physiol 161 11891202

Reddy DS, Bhatnagar-Mathur P, Vadez V and Sharma KK (2012) Grain legumes (Soybean, Chickpea, and Peanut): Omics approaches to enhance abiotic stress tolerance. In: Improving Crop Resistance to Abiotic Stress (Eds: Tuteja N, Gill SS, Tiburcio AF, Tuteja R,) DOI: 10.1002/ 9783527632930.ch39 Wiley-VCH Verlag GmbH \& Co. $\mathrm{KGaA}$

Rowe HC, Hansen BG, Halkier BA and Kliebenstein DJ (2008) Biochemical networks and epistasis shape the Arabidopsis thaliana metabolome Plant Cell 20 1199-1216

Scofield SR and Nelson RS (2009) Resources for virus-induced gene silencing in the grasses Plant Physiol 149 152-157

Sehgal D, Rajaram V, Armstead IP, Vadez V, Yadav YP, Hash CT 
and Yadav RS (2012) Integration of gene-based markers in a pearl millet genetic map for identification of candidate genes underlying drought tolerance quantitative trait loci BMC Plant Biol 129

Seki M, Narusaka M, Ishida J, Nanjo T, Fujita M, Oono Y, Kamiya A, Nakajima M, Enju A, Sakurai T, Satou M, Akiyama K, Taji T, Yamaguchi-Shinozaki K, Carninci P, Kawai J, Hayashizaki Y and Shinozaki K (2002) Monitoring the expression profiles of 7000 Arabidopsis genes under drought, cold, and high salinity stresses using a full-length cDNA microarray Plant J 31 279-292

Senthilvel S, Jayashree B, Mahalakshmi V, Kumar PS, Nakka S, Nepolean T and Hash C (2008) Development and mapping of simple sequence repeat markers from pearl millet from data mining of expressed sequence tags BMC Plant Biol $\mathbf{8}$ 119

Serraj R, Hash CT, Rizvi SMH, Sharma A, Yadav RS and Bidinger FR (2005) Recent advances in marker-assisted selection for drought tolerance in pearl millet Plant Prod Sci 8334 337

Sharma PC, Sehgal D, Singh D, Singh G and Yadav RS (2011) A major terminal drought tolerance QTL of pearl millet is also associated with reduced salt uptake and enhanced growth under salt stress Mol Breed 27 207-222

Sharma PC, Singh D, Sehgal D, Singh G, Hash CT and Yadav RS (2014) Further evidence that a terminal drought tolerance QTL of pearl millet is associated with reduced salt uptake Environ Exp Bot 102 48-57

Shulaev V, Cortes D, Miller G and Mittler R (2008) Metabolomics for plant stress response Physiol Plant 132 199-208

Singh UM, Chandra M, Shankdhar SC and Kumar A (2014) Transcriptome wide identification and validation of calcium sensor gene family in the developing spiles of finger millet genotypes for elucidating its role in grain calcium accumulation PLoS One 9 e 103963

Solanke AU and Mithra SVA (2013) Genetics and genomics resources in finger millet- a climate resilient nutria-millet Biotech Articles http://www.biotecharticles.com/BiotechResearch-Article/Genetic-and-Genomics-Resources-inFinger-Millet-3098.html

Sreenivasulu N, Miranda M, Prakash HS, Wobus U and Weschke W (2004) Transcriptome changes in foxtail millet genotypes at high salinity: identification and characterization of a PHGPX gene specifically upregulated by $\mathrm{NaCl}$ in a salttolerant line J Plant Physiol 161 467-477

Srinivasachary, Dida MM, Gale MD and Devos KM (2007) Comparative analyses reveal high levels of conserved colinearity between the finger millet and rice genomes Theor
Appl Genet 115 489-99

Sumner LW, Mendes P and Dixon RA (2003) Plant metabolomics: large scale phytochemistry in the functional genomics era Phytochem 62 817-836

Supriya, Senthilvel S, Nepolean T, Eshwar K, Rajaram V, Shaw R, Hash CT, Kilian A, Yadav RC and Narasu ML (2011) Development of a molecular linkage map of pearl millet integrating DArT and SSR markers Theor Appl Genet $\mathbf{1 2 3}$ 239-250

Suresh BV, Muthamilarasan M, Mishra G and Prasad M (2013) FmMDb: A versatile database of foxtail millet markers for millets and bioenergy grasses research PLOS ONE 8 e71418

Taylor MG, Vasil V and Vasil IK (1991) Histology of and physical factors affecting, transient GUS expression in pearl millet (Pennisetum glaucum (L.) R. Br.) embryos following microprojectile bombardment Plant Cell Rep 10 120-125

Turina M, Maruoka M, Monis J, Jackson AO and Scholthof KBG (1998) Nucleotide sequence and infectivity of a fulllength cDNA clone of Panicum mosaic virus Virology 241 141-155

Upadhyaya HD, Gowda CLL, Pundir RPS, Reddy VG and Singh $S$ (2006) Development of core subset of finger millet germplasm using geographical origin and data on 14 quantitative traits Genet Resource Crop Evol 53 679-685

Vadez V, Hash T, Bidinger FR and Kholova J (2012) Phenotyping pearl millet for adaptation to drought Front Physiol 3386

Vadivoo AS, Joseph R and Ganesan NM (1998) Genetic variability and diversity for protein and calcium contents in finger millet (Eleusine coracana (L.) Gaertn) in relation to grain color Plant Foods Hum Nutr 52 353-64

van Nugteren, Hein I and Berger DK (2007) Development of a virus-induced gene silencing system in pearl millet South African J Bot $\mathbf{7 3} 339$

Veeranagamallaiah G, Jyothsnakumari G, Thippeswamy M, Reddy PCO, Surabhi G-K, Sriranganayakulu G, Mahesh Y, Rajasekhar B, Madhurarekha C and Sudhakar C (2008) Proteomic analysis of salt stress responses in foxtail millet (Setaria italica L. cv. Prasad) seedlings Plant Sci 175 631641

Veluthambi K, Gupta K and Sharma A (2003) The current status of plant transformation technologies Curr Sci 84 368-380

Vetriventhan M, Upadhyaya HD, Anandakumar CR, Senthilvel S, Varshney RK and Parzies HK (2014) Population structure and linkage disequilibrium of ICRISAT foxtail millet (Setaria italica (L.) P. Beauv.) core collection Euphytica 196 423-435

Wang ZM, Devos KM, Liu CJ, Wang RQ and Gale MD (1998) Construction of RFLP-based maps of foxtail millet, Setaria 
italica (L.) P. Beauv Theor Appl Genet 96 31-36

Wang C, Jia G, Zhi H, Niu Z, Chai Y, Li W, Wang Y, Li H, Lu P, Zhao B and Diao X (2012) Genetic diversity and population structure of Chinese foxtail millet [Setaria italica (L.) Beauv.] landraces G3 (Bethesda) 2 769-777

Watkinson JI, Hendricks L, Sioson AA, Heath LS, Bohnert HJ and Grene R (2008) Tuber development phenotypes in adapted and acclimated, drought-stressed Solanum tuberosum ssp. andigena have distinct expression profiles of genes associated with carbon metabolism Plant Physiol Biochem 46 34-45

Xu J, Li Y, Ma X, Ding J, Wang K, Wang S, Tian Y, Zhang H and Zhu XG (2013) Whole transcriptome analysis using nextgeneration sequencing of model species Setaria viridis to support $\mathrm{C}_{4}$ photosynthesis research Plant Mol Biol 83 7787

Yadav CB, Bonthala VS, Muthamilarasan M, Pandey G, Khan Y and Prasad M (2014a) Genome-wide development of transposable elements-based markers in foxtail millet and construction of an integrated database DNA Res doi: 10.1093/dnares/dsu039

Yadav CB, Muthamilarasan M, Pandey G, Khan Y and Prasad M (2014b) Development of novel microRNA-based genetic markers in foxtail millet for genotyping applications in related grass species Mol Breed doi:10.1007/s11032-0140137-9

Yadav CB, Muthamilarasan M, Pandey G and Prasad M (2014c) Identification, characterization and expression profiling of Dicer-like, Argonaute and RNA-dependent RNA polymerase gene families in foxtail millet Plant Mol Biol Rep doi: 10.1007/s11105-014-0736-y

Yadav OP, Mitchell SE, Zamora A, Fulton TM and Kresovich S (2007) Development of new simple sequence repeat markers for pearl millet SAT eJournal 3

Yadav RS, Bidinger FR, Hash CT, Yadav YP, Yadav OP, Bhatnagar SK and Howarth CJ (2003) Mapping and characterisation of QTL $\times$ E interactions for traits determining grain and stover yield in pearl millet Theor Appl Genet 106 512-520

Yadav RS, Hash CT, Bidinger FR, Cavan GP and Howarth CJ (2002) Quantitative trait loci associated with traits determining grain and stover yield in pearl millet under terminal drought stress conditions Theor Appl Genet 104 67-83

Yadav RS, Hash CT, Bidinger FR, Devos KM and Howarth CJ (2004) Genomic regions associated with grain yield and aspects of post flowering drought tolerance in pearl millet across stress environments and tester background Euphytica 136 265-277
Yadav RS, Sehgal D and Vadez V (2011) Using genetic mapping and genomics approaches in understanding and improving drought tolerance in pearl millet J Exp Bot 62 397-408

Yang W, Duan L, Chen G, Xiong L and Liu Q (2013) Plant phenomics and high-throughput phenotyping: accelerating rice functional genomics using multidisciplinary technologies Curr Opi Plant Biol 16 180-187

Yin H, Yu Q, Dai Y, An L and Li W (2014) Transcript profiling of foxtail millet seedlings under drought condition and discovery of a new drought- tolerant gene In: 1 st International Setaria Genetics Conference, pp 24

Yue J, Li C, Liu Y and Yu J (2014) A Remorin gene SiREM6, the target gene of SiARDP, from foxtail millet (Setaria italica) promotes high salt tolerance in transgenic Arabidopsis $P L o S$ ONE 9 e 100772

Zeller G, Henz SR, Widmer CK, Sachsenberg T, Rätsch G, Weigel D and Laubinger S (2009) Stress-induced changes in the Arabidopsis thaliana transcriptome analyzed using wholegenome tiling arrays Plant J 58 1068-1082

Zeng Y, Conner J and Ozias-Akins P (2011) Identification of ovule transcripts from the apospory-specific genomic region (ASGR)-carrier chromosome BMC Genomics 12 206 doi: 10.1186/1471-2164-12-206

Zhang G, Liu X, Quan Z, Cheng S, Xu X, Pan S, Xie M, Zeng P, Yue Z, Wang W, Tao Y, Bian C, Han C, Xia Q, Peng X, Cao R, Yang X, Zhan D, Hu J, Zhang Y, Li H, Li H, Li N, Wang J, Wang C, Wang R, Guo T, Cai Y, Liu C, Xiang H, Shi Q, Huang P, Chen Q, Li Y, Wang J, Zhao Z and Wang J (2012) Genome sequence of foxtail millet (Setaria italica) provides insights into grass evolution and biofuel potential Nature Biotechnol 30 549-554

Zhang J, Liu T, Fu J, Zhu Y, Jia J, Zheng J, Zhao Y, Zhang Y and Wang G (2007) Construction and application of EST library from Setaria italica in response to dehydration stress Genomics 90 121-131

Zhang S, Tang C, Zhao Q, Li J, Yang L, Qie L, Fan X, Li L, Zhang N, Zhao M, Liu X, Chai Y, Zhang X, Wang H, Li Y, Li W, Zhi H, Jia G and Diao X (2014) Development of highly polymorphic simple sequence repeat markers using genome-wide microsatellite variant analysis in foxtail millet [Setaria italica (L.) P. Beauv] BMC Genomics 215

Zhu C, Ming C, Zhao-shi X, Lian-Cheng Li, Xue-ping $\mathrm{C}$ and You-zhi Ma (2014) Characteristics and expression patterns of the aldehyde dehydrogenase (ALDH) gene superfamily of foxtail millet (Setaria italica L.) PLOS ONE 9 e101136. 